\title{
Spermatogenesis in Backcross Generations of European Bison and Domestic Cattle Hybrids
}

\author{
Stanisław FEDYK \& Małgorzata KRASIŃSKA
}

\begin{abstract}
Fedyk S. \& Krasińska M., 1980: Spermatogenesis in backcross generations of European bison and domestic cattle hybrids. Acta theriol., 25, 15: 201-212 [With 3 Tables, 2 Figs. \& Plates VIII-IX]

The paper presents the results of histomonphological studies on the testes of European bison and domestic cattle hybrids ( 6 individuals of generation $\mathrm{B}_{2}-1 / 8$ European bison; $1 \mathrm{~B}_{3}$ 1/16 European bison; $1 \mathrm{~F}_{1}$ ). A morphological description of the testes is given and the course of spermatogenesis traced. No differences in the dimensions of seminiferous tubulae were found in the material examined. In the $F_{1}$ hybrid and in $\mathrm{B}_{2}$ hybrids spermatogonia only were observed. In a further two $\mathrm{B}_{2}$ hybrids primary and secondary spermatocytes were found to be present. Complete spermatogenesis took place in the other $3 \mathrm{~B}_{2}$ hybrids and in the $\mathrm{B}_{3}$ hybrid. The amount of spermatogonia per constant area of the tubulae is similar in hybrids of all backeross generations $\left(\mathrm{B}_{1}, \mathrm{~B}_{2}, \mathrm{~B}_{3}\right)$, and three times greater than in $F_{1}$ hybrids. The numbers of cells of the remaining stages of spermatogenesis increase with increasing percentage of cattle blood.

[Mammals Res. Inst., Polish Acad. Sci., 17-230 Białowieża, Poland]
\end{abstract}

\section{INTRODUCTION}

Hybrids obtained by crossing European bison with domestic cattle possess a large number of characteristics of benefit from the breeding point of view ( $\mathrm{Kras}$ ińska, 1969, P i etrzykowski \& Krasiń$\mathrm{ska}, 1971, \mathrm{Szulc}$ et al., 1971). On this account studies have been undertaken of recent years in Poland on the hybridization of these two species under breeding farm conditions, using insemination of cows with frozen European bison sperm ( $\mathrm{M}$ a $1 \mathrm{eck}$ a et al., 1976). These experiments point to the possibility of future production of hybrids on a wider scale, and its unquestionably useful aspect. In connection with these studies the question of hybrid fertility becomes of considerable importance.

Hybrids of American bison and domestic cattle were obtained on a large scale at the Canada Agriculture Experimental Farm. Testes from this material have been examined both cytologically and histologically. In hylbrids with $22 \%$ bison blood spermatogenesis occurred, 
but normal conjugation in meiosis did not take place in animals with more than $14 \%$ bison blood (P e ters, 1964; B a s rur, 1969). The causes of sterility in male hybrids have been sought for among genetic and developmental factors. A critical review of these hypotheses has been presented in the paper on the experiment carried out in Canada (B asrur, 1969), and in the first part of the present study (Fedyk \& Krasińska, 1971).

The breeding experiment carried out at Białowieża produced 31 male hybrids of different generations (1/2 to 1/16 European bison). Despite attempts at mating, none of these males sired any progeny. In an earlier paper (Fedy k \& Kras ińska, 1971) histological examination was made of testes in $F_{1}$ generation males and male backcrosses $\left(B_{1}\right)$ to cattle. The present paper forms a continuation of these studies and relates to $B_{2}$ and $B_{3}$ hybrids (i.e. second and third generation of backcrosses to cattle). In addition a histomorphological description is given of the testes of one $F_{1}$ generation hybrid.

\section{MATERIAL AND METHODS}

The subject of the studies was formed by hybrids of European bison and domestic cattle of the lowland black-and-white and Polish red breeds, obtained at the Mammals Research Institute PAS at Bialowieża during the period from 1971-1974 and one animal born in 1962. Detailed data on these animals are to be found in other studies ( $\mathrm{Kr}$ a s i ńs k a, 1967, 1971, 1979).

The testes for the studies were obtained from animals shot for monphological analysis or from animals which had died naturally. The material consisted of the testes of one $F_{1}$ generation bull, which died at the age of 11 , and $6 \mathrm{~B}_{2}$ generation hybrids (1/8 European bison, 7/8 cattle) aged from 5 months to 4 years, and from one 2-year old hybrid obtained in $B_{3}$ generation (1/16 European bison, $15 / 16$ cattle).

The testes were excised immediately after slaughter and small fragments of them were fixed in Bouin fluid, embedded in paraffin and then sectioned to $10-20 \mu$. The preparations were stained with hematoxylin and eosine.

Microscopic examination was made of 100 tubulae from each individual, recording the stage at which spermatogenesis had ceased. Ten tubulae representing average spermatogenetic activity level were taken from each individual and calculation made of the total number of cells of all stages of spermatogenesis. Using measurements of minimum and maximum diameter of 10 tubulae and the calculated mean length of their radius as a basis, calculation was next made of the area of a cross-section of the tubula. In turn calculation was made of the number of cells at different stages of spermatogenesis per $1000 \mu^{2}$ of tubula area, which made it possible to eliminate differences resulting from different dimensions of the tubulae.

Calculation was also made for hylbrids of all generations of the index of number of Sertoli cells in relation to the numbers of all germ cells per $1000 \mu^{2}$ of tubula.

The significance of differences between values for area of seminiferous tubulae 
and total number of germ cells in hybrids of different generations was found by means of the $t$ Student test.

\section{MICROSCOPIC OBSERVATIONS OF TES'PES}

\subsection{F $_{1}$ hybrid}

The seminiferous tubulae of the $F_{1}$ hybrid (Facet) are loosely arranged, neighbouring tubulae not being in contact through their basement membranes. The relatively large spaces between tubulae are filled with numerous interstitial cells enveloped in connective tissue. The membranes of the tubulae are thickened and consist of several distinct layers. The whole lumen of the tubulae is filled with Sertoli cells and scanty spenmatogonia, and in addition a large amount of detritus and, sporadically, spermiophages, are observed in the tubulae. The walls of the blood vessels are thickened (Plate VIII, a).

\section{2. $B_{2}$ hybrids}

The microscoipic picture of testes in $\mathrm{B}_{2}$ generation hybrids is diversified. Both the full cycle of spermatogenesis, in which the different stages are arranged concentrically, and also cases in which spermatogenesis does not continue to its termination, are observed. Such diversity also applies to interstitial tissue and the arrangement itself of tubulae.

Feston (5 months). The picture observed in this hybrid was normal. The walls of tubulae are in contact and groups of interstitial cells occur in the triangular spaces between them. The basement membranes of the tubulae are thin. The whole lumen of the tubulae is filled with cells (Sertoli cells and a few spermatogonia) and numerous deposits of detritus (Plate VIII, b).

Fenek (one year old). Seen in cross-section the tubulae have irregular folded walls but contact each other. In the spaces between them there are a few interstitial cells. The lumen of the tubulae is filled with a large amount of detritus. All stages of spermatogenesis are prosent (Plate VIII, c).

Fenyl ( 2 years old). The seminiferous tubulae do not touch each other. Bands of connective tissue occur here and there in the large free spaces between them. There are few interstitial cells and they form clusters. The relatively large lumen of the tubulae is filled with detritus. The germ cells form characteristic spermatogenetic waves. The blood vess 1 s have thickened walls and a small lumen (Plate VIII, d).

Fenol (4 years old). In this animal the seminiferous tubulae are in 
contact through their basement membranes, but there are large spaces between them filled with interstitial cells and connective tissue. Sertoli cells are situated near the basement membranes and scanty primary and secondary spermatocytes lie in the lumen. Detritus forms streaks (Plate IX, f).

Fenomen (4 years old). Considerable growth of connective tissue, causing separation of the tubulae, which are only rarely in contact, can be observed in the cross-section of the testis. The whole of the spaces between tubulae are filled with interstitial cells and connective tissue. Sertoli cells and spermatogonia lie near the basement membrane.

Fen II (4 years old). Onily small surfaces of the seminiferous tubulae are in contact and the spaces between them are filled with connective tissue and interstitial cells. Germ cells form spermatogenetic waves. There is a large amount of detritus in the lumen of the tubulae (Plate IX, g).

\subsection{B $_{3}$ hybrids}

Generation $B_{3}$ is represented by one male only (Feliks -2 years old), in which the histological picture of the testes is a normal one. The seminiferous tubulae adhere closely. There are interstitial cells only in the triangular spaces between the tubulae. Germ cells form regular spermatogenetic waves. Scanty detritus occurs in the lumen of the tubulae (Plate IX, i).

\section{EPIDIDYMIS}

As anticipated, no spermatozoa were found to be present in the epididymis of the $F_{1}$ hybrid (Facet), but there was marked growth of interstitial tissue. In $B_{2}$ hybrids, however, the picture is diversified. In the youngest hylbrids (Feston), 5 months old, the epididymis is not completely formed. It has thin walls and a small dumen containing detritus and mucus. Among the three $B_{2}$ hybrids, in the seminiferous tubulae of which spermaltozoa were present, one (Fenyl) has an empty epididymis and the other two (Fenek, Fen II) have epididymis filled with a large amount of spermatozoa (Plate VIII, e and Plate IX, h). In the $\mathrm{B}_{3}$ generation hybrid (Feliks) also, a large amount of spermatozoa were observed in the epididymis.

\section{DIMENSIONS OF SEMINIFEROUS TUBULAE}

In the group of hybrids under discussion, the smallest area of tubulae was found in the youngest hybrid, 5-month old Feston, and also in the oldest $F_{1}$ generation hybrid (11-year old Facet). 


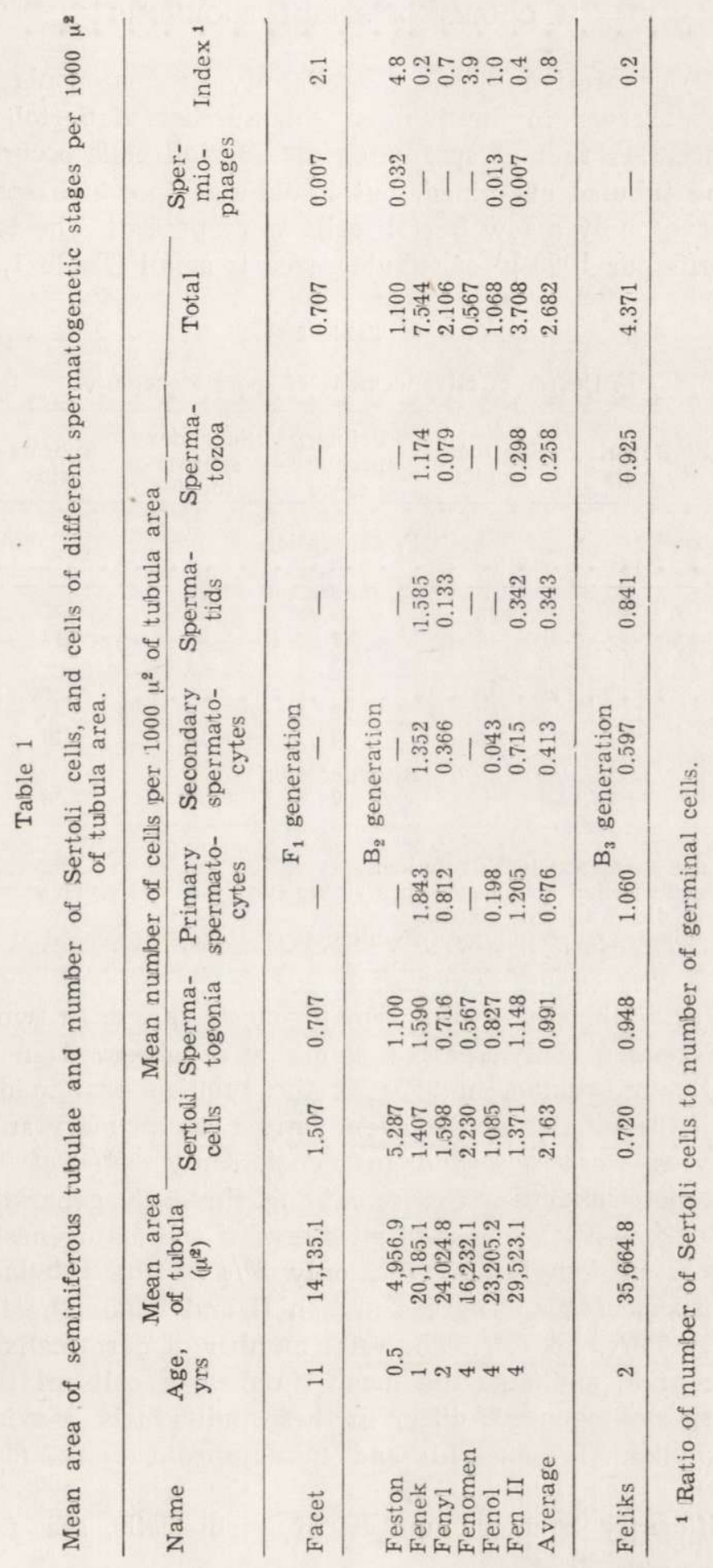




\section{COURSE OF SPERMATOGENESIS}

In the $F_{1}$ generation hybrid (Facet) only spermatogonia and Sertoli cells were observed in the tubulae, the number of Sertoli cells being twice as great as that of spermatogonia. Sertoli cells occurred only in $15 \%$ of the tubulae examined, but in tubulae in which spermatogonia were observed only a few Sertoli cells were present. The total number of germ cells per $1000 \mu^{2}$ of tubulae area is small (Table 1, 2).

Table 2

Degree of advancement of spermatogenesis.

\begin{tabular}{|c|c|c|c|c|c|c|}
\hline Name & $\begin{array}{l}\text { Sertoli } \\
\text { cells }\end{array}$ & $\begin{array}{l}\text { Spermato- } \\
\text { gonia }\end{array}$ & $\begin{array}{c}\text { Primary } \\
\text { spermato- } \\
\text { cytes }\end{array}$ & $\begin{array}{l}\text { Secondary } \\
\text { sperma- } \\
\text { tocytes }\end{array}$ & $\begin{array}{l}\text { Sperma- } \\
\text { tids }\end{array}$ & $\begin{array}{c}\text { Sperma- } \\
\text { tozoa }\end{array}$ \\
\hline Facet & 15 & 85 & $\begin{array}{l}F_{1} \text { generation } \\
B_{0} \text { generation }\end{array}$ & - & - & - \\
\hline Feston & 5 & 95 & $\mathrm{~B}_{2}$ generdain & - & - & - \\
\hline Fenek & + & 3 & 7 & - & 12 & 78 \\
\hline Fenyl & 6 & 24 & 63 & 4 & - & 3 \\
\hline Fenomen & 25 & 75 & - & - & - & - \\
\hline Fenol & 14 & 62 & 22 & 2 & - & - \\
\hline Fen II & + & 3 & 3 & 18 & 10 & 66 \\
\hline Feliks & + & + & $\mathrm{B}_{3}$ generation & 9 & 8 & 74 \\
\hline
\end{tabular}

+ Given stage possessed $100 \%$ tubulae.

- spermatogenesis had not ceased in a single tubula at the given stage, or that the given stage did not occur at all.

Figures - indicates $\%$ of tubulae in which spermatogenesis ceased at a given stage.

In $B_{2}$ hybrids the course of spermatogenesis varied. In two individuals (Feston, Fenomen) only spermatogonia were observed in addition to Sertoli cells in tubulae, in $95 \%$ of the tubulae examined in Feston, and $75 \%$ of the tubulae in Fenomen. Only a few primary and secondary spermatocytes were observed in Fenol. Only $25 \%$ of the tubulae contained spermatocytes. The remaining three $\mathrm{B}_{2}$ generation hybrids (Fenyl, Fenek, Fen II) possessed all stages of spermatogenesis, including spermatozoa. In Fenyl, however, only $3 \%$ of the tubulae examined contained spermatozoa, whereas in Fen II and Fenek the figures were respectively $66 \%$ and $76 \%$. The total number of germ cells per $1000 \mu^{2}$ of tubulae area, and also the mean number of cells of the different stages of spermatogenesis, differ in these individuals. Maximum values occur in Fenek (1 year old $)$ and minimum in Fenyl (2 years old) (Table 1,2).

A significantly greater number of germ cells are found in $B_{2}$ 
generation hybrids than in $\mathrm{B}_{1}(P<0.05)$. All stages of spermatogenesis occurred in the $B_{3}$ generation hybrid, $74 \%$ of the tubulae containing spermatozoa. Relatively large numbers of germ cells per $1000 \mu^{2}$ of tubulae area were also found (Table 1,2). Spermiophages were found to be present in 3 individuals of $\mathrm{B}_{2}$ generation (Fenol, Fen II, Feston), but the numbers were always small.

\section{COMPARISON OF GENERATIONS $\mathrm{F}_{1}, \mathrm{~B}_{1}, \mathrm{~B}_{2}, \mathrm{~B}_{3}$}

It would appear that in $B_{2}$ hybrids is no relation between tubulae dimensions and degree to which spermatogenesis has advanced, spermatogenesis being found earlier in $\mathrm{F}_{1}$ and $\mathrm{B}_{1}$ hybrids ( $\mathrm{Fedyk}$ \& \& Krasinska, 1971). It can only be stated that a greater area of seminiferous tubulae was found in individuals in which spermatozoa were present (Table 1, Fig. 1).

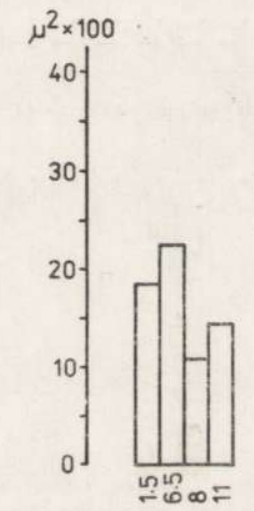

$F_{1}$

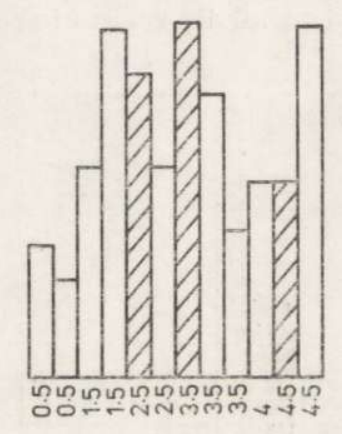

$\mathrm{B}_{1}$

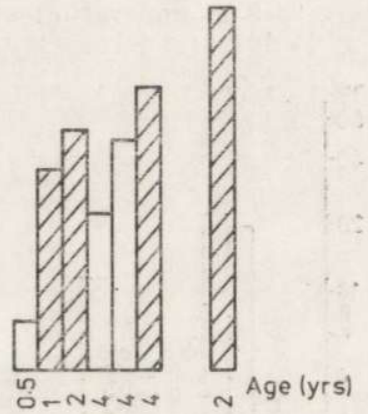

$\mathrm{B}_{2} \quad \mathrm{~B}_{3}$

Fig. 1. Area of seminiferous tubulae (in $\mu^{2} \times 100$ ). Shaded columns refer to individuals in which all stages of spermatogenesis were present.

The size of - seminiferous tubulae area in hybrids of different generations $\left(\mathrm{F}_{1}, \mathrm{~B}_{1}, \mathrm{~B}_{2}\right)$ does not differ significantly (in all cases $\mathrm{P}>0.05$ ), while only the $\mathrm{B}_{3}$ hybrid had a greater tubulae area than hybrid $\mathrm{B}_{2}$.

When comparing material obtained from $F_{1}, B_{1}, B_{2}$ and $B_{3}$ analysis was made of the relation between the degree of advance in spermatogenesis and ratio of the number of Sertoli cells to the total number of germ cells per $1000 \mu^{2}$ of tubulae area (Table 3). Higher values of the index occurred in generations $F_{1}$ and $B_{1}$ than in $B_{2}$ and $B_{3}$. In the animals belonging to the same generation this index is however higher, where there is a lesser degree of advance in spermatogenesis. Maximum 
values of this index occur in backcross generations in which complete spermatogenesis takes place together with spermatozoa production. In such cases the ratio of number of Sertoli cells to germ cells never exceeds the value 1 . In two individuals (Fenek $-\mathrm{B}_{2}$ and Feliks $-\mathrm{B}_{3}$ )

Table 3

Comparison of mean number of germinal cells of different stages of spermatogenesis in $F_{1}-B_{3}$ generations hybrids and European bison.

\begin{tabular}{|c|c|c|c|c|c|c|}
\hline \multirow[b]{2}{*}{$\begin{array}{l}\text { Gene- } \\
\text { ration }\end{array}$} & \multirow[b]{2}{*}{$\mathrm{n}$} & \multicolumn{5}{|c|}{ Mean number of germinal cells $/ 1000 \mu^{2}$ of tubula area } \\
\hline & & $\begin{array}{l}\text { Spermato- } \\
\text { gonia }\end{array}$ & $\begin{array}{l}\text { Primary } \\
\text { spermato- } \\
\text { cytes }\end{array}$ & $\begin{array}{l}\text { Secondary } \\
\text { spermato- } \\
\text { cytes }\end{array}$ & $\begin{array}{l}\text { Sperma- } \\
\text { tids' }\end{array}$ & $\begin{array}{c}\text { Sperma- } \\
\text { tozoa }\end{array}$ \\
\hline & 4 & 0.292 & 0.007 & - & - & - \\
\hline $\mathrm{B}_{1}$ & 11 & 0.946 & 0.434 & 0.058 & 0.012 & 0.020 \\
\hline $\mathrm{B}_{2}$ & 6 & 0.991 & 0.676 & 0.413 & 0.343 & 0.258 \\
\hline $\begin{array}{l}\mathrm{B}_{3} \\
\text { European }\end{array}$ & 1 & 0.948 & 1.060 & 0.597 & 0.841 & 0.925 \\
\hline bison & 1 & 0.643 & 1.080 & 0.768 & 0.695 & 0.413 \\
\hline
\end{tabular}

Data relating to $3 F_{1}$ generation and to all $B_{1}$ generation hybrids are described in the paper by Fedyk and Krasińska, 1971.

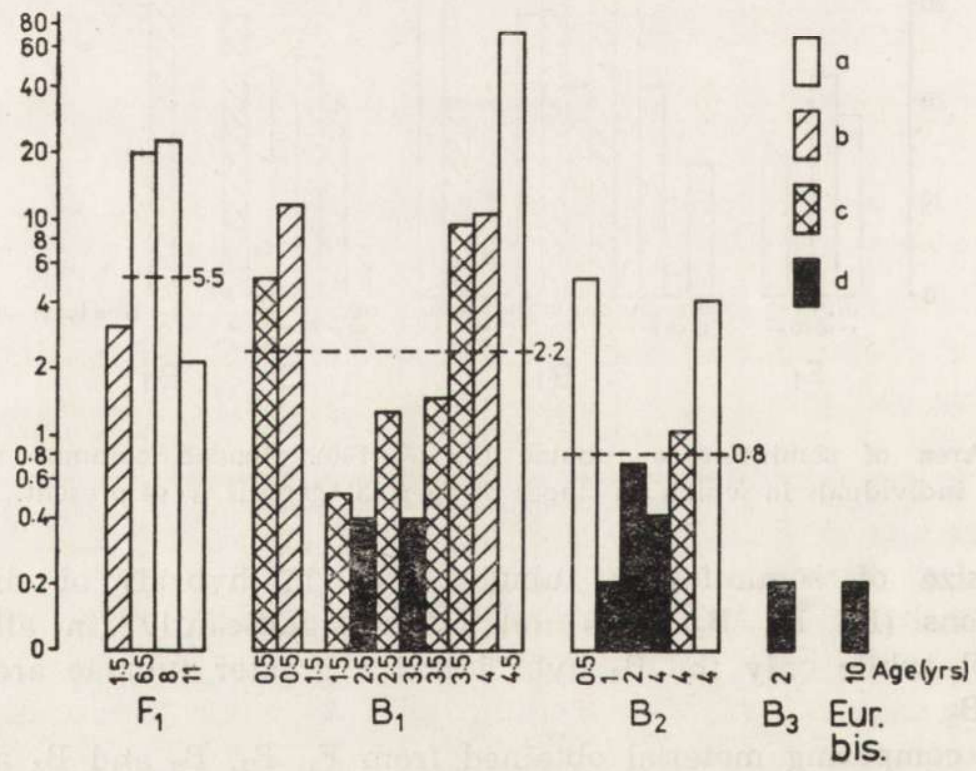

Fig. 2. Ratio of number of Sertoli cells to number of germ cells, values of this index have been marked on logarithmic scale, mean values for different generations indicated with dotted line.

Individuals with varying degree of advanced spermatogenesis have been distinguished in the diagram: only spermatogonia present (a), spermatogenesis continues to primary spermatocyte stage (b), to secondary spermatocyte stage (c), all stages of spermatogenesis, including presence of spermatozoa (d). 
this ratio is lowest $(0.2)-$ Fig. 2. This same index occurs in European bison (Fedyk \& Krasinska, 1971). As the percentage of cattle blood increases in hybrid generations the mean values of the ratio of Sertali cells to germ cells decrease from 5.5 in generation $F_{1}$ to 0.8 in $B_{2}$ (Fig. 2).

\section{DISCUSSION}

The microscopic picture of testes in the $F_{1}$ hybrid (Facet) is similar to that observed in hybrids of the same generation previously examined (F edyk \& Krasinska, 1971), this applying primarily to the membrane structure of seminiferous tubulae and the arrangement of interstitial tissue. In addition, only spermatogonia were found in Facet, as was the case with the two $F_{1}$ hybrids examined earlier.

In a previous paper (Fedyk \& Krasińska, 1971) it was suggested that there is a connection between the size of seminiferous tubulae area and the hybrid's line. The $F_{1}$ hybrid examined in this study belongs to line I (i.e. hybrid from combination of $\delta$ European bison $X$ o cattle). The mean area of its tubulae is distinctly smaller than in the two representatives of this line examined previously. It may therefore be concluded that the diversity observed in $F_{1}$ in the size of tubulae area is more the result of individual variation than the effect of the hybrids' line.

In hydrids of the first backcross generation $\left(\mathrm{B}_{1}\right)$ in many cases degeneration of interstitial tissue and hypertrophy of connective tissue were observed ( $\mathrm{Fedyk} \& \mathrm{Krasinska,1971).} \mathrm{This} \mathrm{was} \mathrm{also} \mathrm{observed}$ in $\mathrm{B}_{2}$ hybrids, although it would appear that the histological picture of intertubular spaces in $\mathrm{B}_{2}$ generation hydrids is closer to normal. On the other hand thickening of the walls of capillary vessels observed in many $F_{1}$ and $B_{1}$ hybrids did not occur at all in $B_{2}$ and $B_{3}$ generations.

In respect of the process of spermatogenesis, in generation $B_{2}$ it either continues to its normal termination or ceases in the spermatogonia stage. It may be concluded that in this second case the reason for cessation of spermatogenesis is to be found in priring abnormalities of chromosomes. An exception is formed by the $\mathrm{B}_{2}$ hybrid Fenol, in which primary and secondary spermatocytes were observed, but spermatids and spermatozoa did not occur. This picture of spermatogenesis was found in the majority of $\mathrm{B}_{1}$ hybrids ( $\mathrm{Fedyk} \& \mathrm{Kr}$ as in $\mathrm{sika}$, 1971). It would appear that in these cases inhibition of spermatogenesis depends to a great degree on additional extra-chromosome factors.

In hybrids of American bison and cattle a considerable percentage of cells with an abnormal number of bivalents $(n \neq 30)$ was found during 
mitotic divisions (B a s r u r, 1969). It may be that a similar situation occurs in hybrids of European bison and cattle.

When comparing hybrids of all the generations examined fundamental differences were found in the dynamics of the spermatogenesis process. In backcross generations the similarity in the number of spermatogonia per $1000 \mu^{2}$ of tubulae area is striking. In generations $B_{2}$ and $B_{3}$ this value is approximately 0.9 (Table 1 ), and is identical with the mean value for generation $B_{1}$, whereas in generation $F_{1}$ this value is three times smaller (Table 3 ). The number of primary spermatocytes is greater with increasing percentage of cattle blood in hybrids. This regularity is maintained in all further stages of spermatogenesis (Table 3 ). In the European bison, however, except for primary and secondary spermatocytes, slightly fewer cells per $1000 \mu^{2}$ occur in the remaining stages than in the hybrid $\mathrm{B}_{3}$ (Table 3 ).

In $B_{2}$ and $B_{3}$ generation hybrids the sum total of germ cells of all stages per $1000 \mu^{2}$ is distinctly higher than in the previous generations. The difference between generations $B_{1}$ and $B_{2}$ is statistically significant $(\mathrm{P}<0.05)$, which is due chiefly to the exceptionally large number of germ cells in the year-old $\mathrm{B}_{2}$ hybrid (Fenek). When this individual is omitted, the difference ceases to be significant $(\mathrm{P}>0.05)$ (Table 1).

Of the three $\mathrm{B}_{2}$ generation hybrids in which all spermatogenetic stages were observed, spermatozoa were found in the epididymis in two of them. $B_{3}$ hybrid also possessed numerous spermatozoa in the epididymis. These are thus the first cases in which spermatozoa were found to be present in the epididymis in Białowieża hybrids. In the $F_{1}$ and $B_{1}$ hybrids examined previously no spermatozoa were found in the epididymis (F e dy k \& Krasinska, 1971).

In hybrids of American bison and domestic cattle several fertile males were obtained in the second backcross generation (12.5\% bison) (B a s rur, 1969). In earlier reports (Boyd, 1914; Goodnight, 1914 - cited after B a s rur, 1969) it was stated that when $F_{1}$ females were backicrossed in both directions it was possible to obtain fertile males, but when fertile males of this generation were crossbred with $F_{1}$ females sterile males were always obtained, as was confirmed in later studies (Logan \& Sylvestre, 1950). Basrur (1969) concludes from these facts that $25 \%$ of bison blood "is probably the maximum bison parentage in a hybrid female that is compatible with the production of fertile males. In general, cattalos with $14 \%$ American bison parentage are found to be fertile".

The histological studies made on hybrids of European bison and domestic cattle would appear to confirm this opinion. Białowieża bred $\mathrm{B}_{2}$ hybrids $(12.5 \%$ cattle $)$ had complete spermatogenesis, while 
spermatozoa were present in the epididymis. Even so, progeny was not obtained from these males as the result of natural mating. As additional studies were not carried out on the quality of spermatozoa no opinion can be given as to the causes of ineffective mating. It can only be assumed that the cause might have been the low viability of spermatozoa or the presence of their abnormal forms, which have been observed by B a s r u r (1969) in American hybrids. It must, however, be remembered that in Białowieża studies only 7 individuals of the final backcross generations were available (this including one $B_{3}$ generation animal), and such scanty material cannot form proof that completely fertile males cannot occur in these generations.

\section{REFERENCES}

1. Basrur P. K., 1969: Hybrid sterility. [In: "Comparative Mammalian Cytogenetics«, K. Benirschke, ed.]. Springer Verlag: 107-131. New York.

2. Fedyk S. \& Krasińs ka M., 1971: Studies on spermatogenesis of domestic cattle and European bison hybrids. Acta theriol., 16: 465-470.

3. Kra sińs k a M., 1967: Crosses of wisent and domestic cattle. V. Acta theriol., 12: $67-80$.

4. Krasinsk a M., 1969: The postnatal development of $F_{1}$ hybrids of European bison and domestic cattle. Acta theriol., 14: 69-117.

5. Krasińska M., 1971: Hybridisation of European bison with domestic cattle. Part VI. Acta theriol., 16: $413-422$.

6. Krasińska M., 1979: Progress in breeding European bison and domestic cattle hybrids and casuistics in cases of immobilization and pasteurelosis in hybrids. Acta theriol., 24: 201-210.

7. Logan V. S., \& Sylvestre P. E., 1950: Hybridisation of domestic beef cattle and buffalo. Experim. Farms Serv. Dept. Agric. Ottawa, Ontario: 1-7.

8. Malecka G., Lamperski B. \& Sumiński E., 1976: Podstawowe zagadnienia inseminacji krów nasieniem żubra. Przegląd hodowlany, 12: 15-19.

9. Peters H. F., 1964: Experimental hybridization of domestic cattle and American bison. Vth Int. Congr. Anim. Reprod., 7: 326-332.

10. Pietrzykowski W. \& Krasińska M., 1971: Characteristic of the skin of European bison and domestic cattle. Acta theriol., 16: 505-512.

11. Szulc M., Tropilo J. \& Krasińska M., 1971: Dressing percentage and utility value of the meat of European bison and domestic cattle hybrids. Acta theriol., 16: 483-504.

Accepted, January 15, 1980.

Stanisław FEDYK \& Malgorzata KRASIŃSKA

\section{SPERMATOGENEZA U WSTECZNYCH POKOLEN HYBRYDOW ŻUBRA Z BYDEEM DOMOWY'M}

W pracy przedstawiono wyniki badań nad spermatogenezą hybrydów żubra $\mathrm{z}$ bydłem domowym dwóch pokoleń wstecznych uzyskanych w Białowieży. Dyspo-

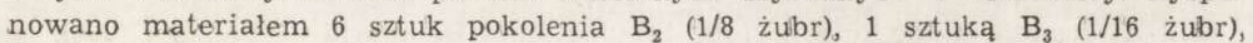


dodatkowo przebadano też jednego hybryda $F_{1}$. Uzyskane wyniki porównano $\mathrm{z}$ danymi dla pokoleń $\mathrm{F}_{1}$ i $\mathrm{B}_{1}$. Określano średnią powierzchnię kanalików nasiennych, ilość poszczególnych stadiów spermatogenezy na $1000 \mu^{2}$ powierzchni oraz stosunek komórek Sertoliego do ilości wszystkich komórek rozrodezych, przypadających na $1000 \mu^{2}$ powierzchni kanalików.

Wielkości powierzchni kanalików hybrydów pokolenia $B_{2}, B_{1}$ i $F_{1}$ nie różnią się istotnie. Jedyny hybryd $\mathrm{B}_{3}$ mial powierzchnię większą niż hybrydy pokolenia $\mathrm{B}_{2}$ (Tabela 1). W pokoleniu $B_{2}$ nie stwierdzono wyraźnej zależności między rozmiarami kanalików a stopniem zaawansowania spermatogenezy, jedynie stwierdzono, że u osobników posiadających plemniki, powierzchnia kanalików nasiennych jest większa (Tabela 1, Ryc. 1).

U hybryda $F_{1}$ oraz u 2 osobników $B_{2}$ obserwowano jedynie obecność spermatogonii, $\mathrm{u}$ trzeciego hybryda $\mathrm{B}_{2}$ występowaly dodatkowo nieliczne spermatocyty I i II rzędu. Natomiast 3 pozostale samce $B_{2}$ miały wszystkie stadia spermatogenetyczne łącznie z plemnikami (Tabela 2).

Srednia ilość spermatogonii przypadająca na $1000 \mu^{2}$ powierzchni kanalika jest podobna $u$ wszystkich hybrydów pokoleń wstecznych natomiast $\mathrm{w}$ pokoleniu $\mathrm{F}_{1}$ trzykrotnie niższa. Srednia ilość komórek pozostałych stadiów spermatogenetycznych wzrasta wraz ze wzrostem udziału krwi bydła w kolejnych pokoleniach hybrydów (Tabela 3). Natomiast $\mathrm{w}$ odwrotnej kolejności maleją średnie wartości stosunku komórek Sertoliego do komórek rozrodezych z $5,5 \quad \mathrm{w}^{\mathrm{F}} \mathrm{F}_{1}$ do 0,8 w $\mathrm{B}_{2}$ (Ryc. 2). $\mathrm{W}$ badanym materiale po raz pierwszy dla hybrydów bialowieskich stwierdzono obecność plemników w kanale najądrza (2 przypadki $B_{2}$ i 1 w $B_{3}$ ). Uzyskane wyniki porównano $\mathrm{z}$ danymi dla hybrydów bizona $\mathrm{z}$ bydłem podobnych pokoleń.

\section{EXPLANATION OF PLATES}

Plate VIII.

a - Cross-section of a testis from $F_{1}$ hybrid - Facet. Note lack of spermatogenesis $(\times 190)$.

b-Cross-section of the seminiferous tubulae from a 5 months old $B_{2}$ hybrid Feston. Note small diameter of the tubulae $\left(X_{190)}\right.$.

c - Cross-section of the testis from $B_{2}$ hybrid - Fenek $(\times 190)$.

$d-$ Cross-section of the testis from $B_{2}$ hybrid - Fenyl. Note large free spaces between seminiferous tubulae $\left(X_{190}\right)$.

e - A section of the epididymis with spermatozoa and spermiophage (arrow) from $B_{2}$ hybrid - Fenek $\left(\times_{190)}\right.$.

Plate IX.

$f-$ Cross-section of the seminiferous tubulae from $B_{2}$ hybrid - Fenol $\left(\times_{190}\right)$. $\mathrm{g}-$ Cross-section of a testis from $\mathrm{B}_{2}$ hybrid - Fen II $\left(X_{190)}\right.$.

$\mathrm{h}-$ Cross-section of the epididymis with spermatozoa, $\mathrm{B}_{2}$ hybrid - Fen II $(\times 190)$.

i - A section of the seminiferous tubulae from $B_{3}$ hybrid - Feliks $\left(X_{190)}\right.$. 


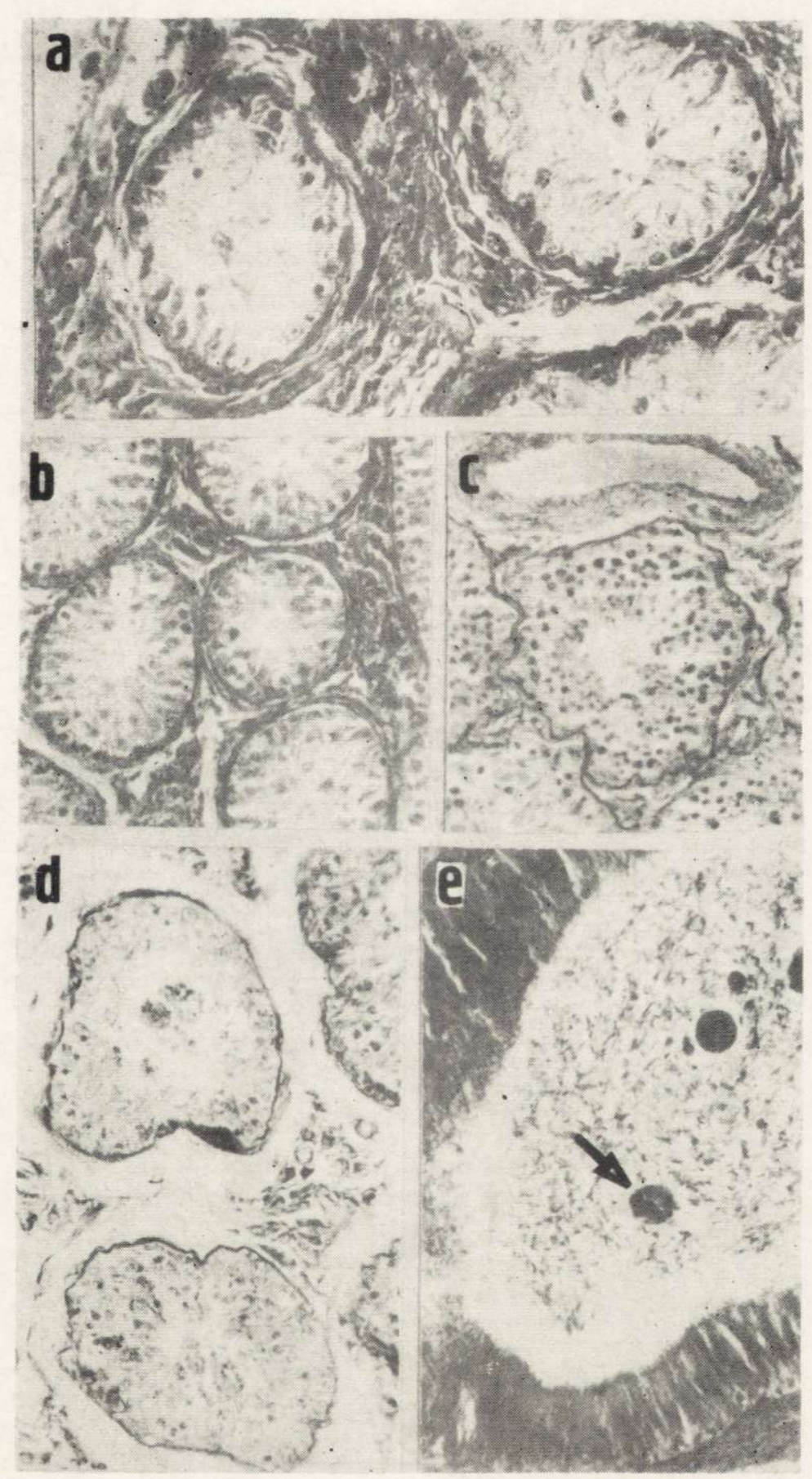




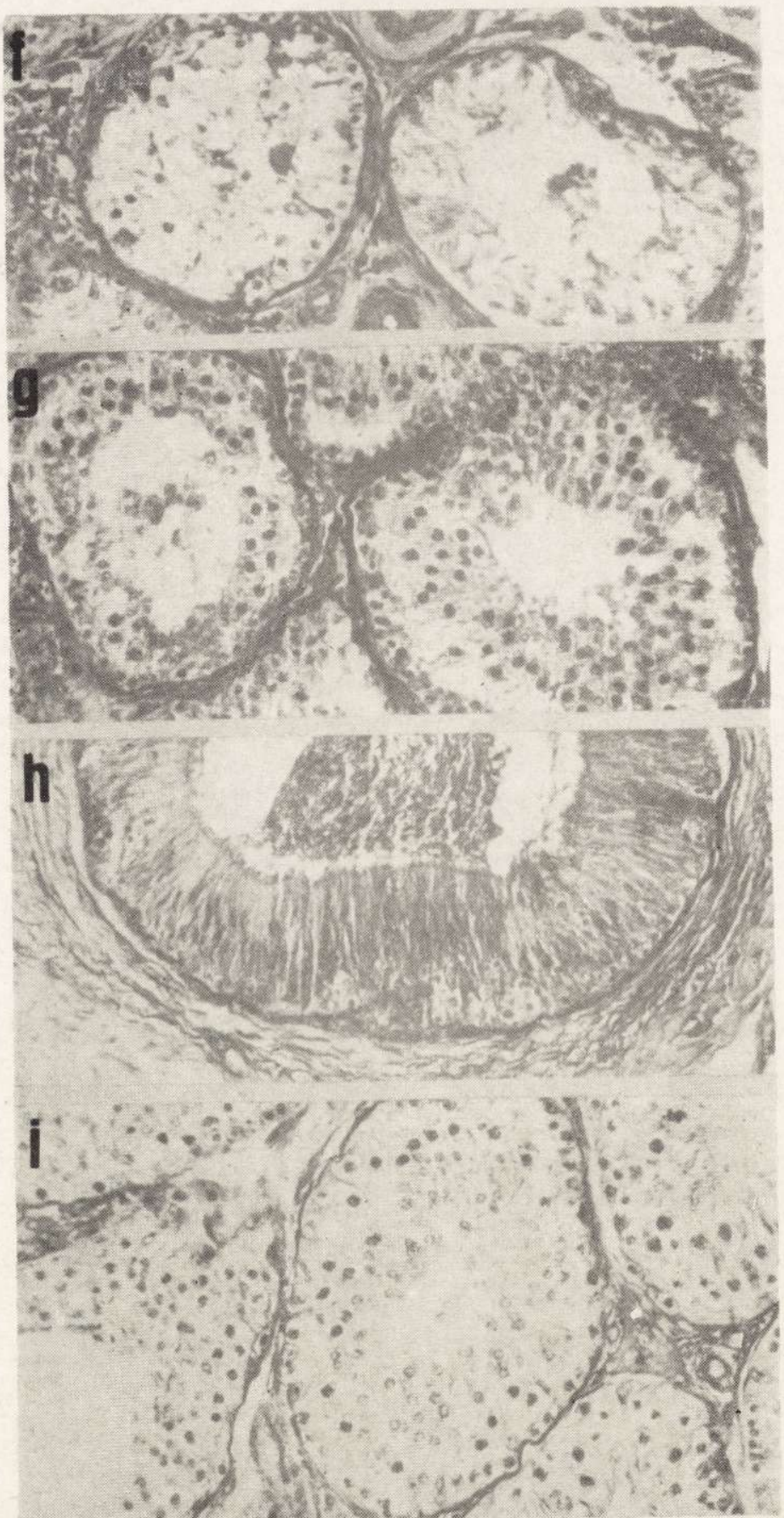

